\title{
Legal and Institutional Framework on Counter-Terrorism in Indonesia
}

\author{
Sri Suatmiati ${ }^{1}$, Edy Kastro ${ }^{2}$ \\ ${ }^{1}$ Legal Studies Postgraduate Program, Universitas Muhammadiyah Palembang, Indonesia. \\ E-mail: srisuatmiati@yahoo.com \\ ${ }^{2}$ Faculty of Law, Universitas Muhammadiyah Palembang, Indonesia. E-mail : edy.kastro@gmail.com
}

\begin{tabular}{l} 
ARTICLE INFO \\
\hline Keywords: \\
terrorism; legal framework; \\
institutional framework \\
How to cite: \\
Suatmiati, S. E Kastro, E. \\
(2020). Legal and \\
Institutional Framework \\
on Counter-Terrorism in \\
Indonesia. JURNAL \\
MEDIA HUKUM, $27(1)$, \\
68-78. \\
Article History: \\
Received: 02-05-2019 \\
Reviewed: 08-11-2019 \\
Revised: 04-06-2020 \\
Accepted: 24-06-2020
\end{tabular}

\begin{abstract}
The current legal basis for combating terrorism in Indonesia is The Government Regulations in Lieu of Statute (Perpu) No. 1 of 2002 on the Eradication of Terrorism. The fight against terrorism involves various institutions including national police, national army, and civil society. With regard to this, special unit has been established to deal with terrorism by national police and national army as well. This paper aims at elaborating the legal and institutional framework for combating terrorism in Indonesia and the possible way to improve it. This normative legal research employs statutory approach. It is found that basically the existing law has been strong enough. However, the eradication of terrorism would be more effective if Indonesia adopt preventive detention clause as governed under the Internal Security Act (ISA) in Singapore and Malaysia. This clause allows the authority to detain the suspect without legal process when his action is considered as the threat of national security.
\end{abstract}

DOI: 10.18196/jmh.20200143

Copyright @ 2020 MEDIA HUKUM. All rights reserved.

\section{Introduction}

Terrorism is a crime againts humanity and civilization and therefore the enemy of all nations and religions. All nations and religions in the world have the same commitment in fighting against terrorism. Literally, the word terror means an effort to create fear upon someone or a group of person. In some cases, terrorists carried out their actions in the name of religion and declared people outside their groups as infidels. It is common among the them to use high explosive bombs such as TNT, C-4, and Semtek.

The issue of international terrorism has become the most widely reported crimes within online media throughout the world in 2015. International terrorism has been reported 104,061 times or 78.2 percent of six different topics in the category of 
international crime. The six topics include international terrorism, drug trafficking, human trafficking, cyber crime, human smuggling, and arms smuggling. ${ }^{1}$

UN General Assembly Resolution 49/60 dated December 9, 1994 affirms that terrorism, as a criminal act intended to provoke a state of terror in the general public by a group of people political purposes under any circumstances, cannot be justified regardless of political considerations, philosophical, ideological, racial, ethnic, religious, or other things that might be used to justify it.

In Indonesia, the discourse on terrorism is sometimes associated with religion. According to some academicians, the emergence of terrorism is triggered by religious radicalism. Bombing attacks have occurred in various places in Indonesia since the 1980s and have become increasingly common in the 2000s and onward.

Factors that rises religious radicalism include economic, social, political issues, differences in ideas, and principles that can lead to the spirit of anti Pancasila (state ideology). ${ }^{2}$ Religious radicalism will continue to flourish in Indonesia if the state does not try as much as possible to prevent and crack down on people with radical understandings using bomb and violence that ravage national unity.

The terrorist attacks that occurred in Indonesia can be categorized by the Rome Statute as a crime against humanity with widespread and systematic characteristics and directed towards the civilian population. The terrorist bommbings caused many deaths and injuries, as well as sadness for everyone, especially the families which loss their members due to terrorism. Even so, terrorism still exists and becomes a burden that must be dealt with by countries around the world because the root of terrorism cannot be optimally overcome yet. Even as we know from print and electronic media, our neighboring country, the Philippines, has been the target. A group of terrorists came and ransacked the peace in Marawi City.

Indonesia must take any necessary action immediately to prevent the transfer of terrorism supporting cells to this country. The battle field has moved to Southeast Asia, so that strategic steps must be taken by the Indonesian National Police and Army to prevent any terrorist attacks happening in the country

\section{Method}

The type of this research is normative legal research that is descriptive in nature. Data were collected through library-based study from various sources such as laws, books, journals and internet assessed, relevant to the problems that will be discussed in this study. ${ }^{3}$ The analysis is focused in terms of legal normative nature, meaning that studies are only based on theories by analyzing various aspects related to the subject matter.

\footnotetext{
${ }^{1}$ Bappenas, Pencegahan dan Penanggulangan Terorisme. http://www.bappenas.go.id/get-fileserver/node/6159/ [Accessed on August ,1, 2018].

2 Ghufron. (2017). Radikalisme dan Politik Identitas. http://nasional.kompas.com/read/2017/05/05/19170871/radikalisme-dan-politik-identitas.

3 Amiruddin \& Asikin, Z. (2004). Pengantar Metode Penelitian Hukum. PT. Rajagrafindo Persada, p. 89.
} 


\section{Analysis and Results}

\subsection{Legal and Institutional Framework on Counter-Terrorism in Indonesia}

During the decades after 1998 reformation, Indonesia recorded several major terrorist bombings including the JSE bomb to JW Marriot Hotel and the Ritz-Carlton Hotels bomb. Most of them are suicide bombings where the terrorists attached bombs to their bodies so the bodies exploded along with bomb explosions. As such, they can attack targets effectively. Hundreds of victims suffering from these incident. Furthermore, these attacks also brought about other negative impacts to the society such as fear and distrust to each other.

It is not exaggerating to qualify terrorism as a crime against humanity, a form of denial against human existence, with all the complexity of life. According to Golose the word "terror" comes from the Latin "Terrorem" which means extraordinary fear. ${ }^{4}$ B.J. Habibie, a former President of Indonesia, describes terrorism as an act of terror or acts of violence carried out in a systematic and unpredictable manner carried out against the State, administrators of both the Executive and the legislature even to social citizens and the political elite of terrorists. ${ }^{5}$

While The Laquer, after reviewing more than one hundred definitions of terrorism, concluded that there were the most prominent elements of the definition, namely that the main character of terrorism was using violence/threats of violence while politically motivated terrorism was often carried out due to the encouragement of religious fanaticism. ${ }^{6}$ Mulyana W Kusumah in his book "Terrorism in Political and Legal Perspectives", explained that terrorism is more clearly a scourge for modern civilization. The nature of the actions, actors, goals, strategic motivations of the expected results and achievements, targets and methods of terrorism are increasingly widespread and diverse. Thus, it is clear that terror is not an ordinary crimes of violence, but crime against mainkind peace and security. ${ }^{7}$ According to Wilkinson, as quoted by Gunawan Permadi, there are three types of terrorism in general: 8

1. Revolutionary Terrorism, namely the use of systematic violence with the ultimate goal of bringing radical changes in the political order;

2. Sub-Revolutionary Terrorism is the use of terrorist forces to cause changes in public policy without changing the political order;

3. Repressive Terrorism, namely the use of violence to suppress terrorists or chain individuals or groups from other forms of behavior that are deemed unacceptable to the State.

\footnotetext{
${ }^{4}$ Golose, P.R. (2010). Deradikalisasi Terorisme Human Soul Approach dan Menyentuh Akar Rumput, Yayasan Pengembangan Kajian Ilmu Kepolisian, p. 2.

5 Ucu, R. (2012). Perlu Strategi Baru Hadapi Terorisme. https://www.republika.co.id/berita/nasional/umum/12/03/16/m0zhsb-habibie-perlu-strategi baru hadapi-terorisme [Accessed on July 28, 2012].

${ }^{6}$ Alex Schmid. 2004. The Defitional Problem. British Ambassador to the United Nations, in post September 11, 2001.

7Mulyana, W Kusuma, M.W. Terorisme Dalam Perspektif Politik dan Hukum. https://media.neliti.com/media/publications/4223-ID-terorisme-dalam-perspektif-politik-danhukum.pdf [Accessed on December 22-29, 2002].

8 Wardlaw, G. (2017). Political Terrorism. Cambridge University Press, p. 100.
} 
Counter-terrorism has become a global movement involving all people in the world including Indonesians. Many efforts have been carried out by governmental institutions to limit the space and prevent or anticipate the movement of terrorist. The criminal policy on terrorism in Indonesia is reflected by the issuance of relevant legislations such as The Government Regulation in Lieu of Statute (Perpu) No. 1 of 2002 on Eradication of Terrorism (strengthened to Law Number 15 of 2003) and Law No. 9 of 2013 on Prevention and Eradication of Terrorist Funding. In addition, antiterror units have also been established both $\mathrm{n}$ national police and army. Counterterrorism also get supports from the non-governmental institutions. ${ }^{9}$

The settlement of criminal cases, including terrorism, are carried out through the criminal justice system. Recently, the Criminal Justice System has been operated as mechanism for anticipating crimes. The term criminal justice system according to Ramington and Ohlin as quoted by Romli Atmasasmita can be interpreted as the use of an approach to the mechanism of criminal justice administration, and criminal justice as a system is the result of interaction between laws, administrative practices and behavior or social behavior. ${ }^{10}$

The meaning of the system itself implies the interaction process that is prepared rationally and efficiently to provide specific results with all its limitations. Marjono Reksodipoetro imposes that the criminal justice system is a crime control system consisting of the Police, Prosecutors' Office, Courts and Correctional Institutions. Based on Marjono's point of view, the components of the criminal justice system are the Police, Prosecutor, Courts, and Correctional Institutions. Furthermore, Marjono also stated that the purpose of the criminal justice system is to prevent the public from becoming victims of crime, to resolve crimes so that the community is satisfied that justice has been upheld. Muladi suggested that the criminal justice system is a judicial network that uses substantive criminal law, procedural criminal law, or legal implementation. But this institution must be seen in a social context. ${ }^{11}$

This is intended to achieve justice in accordance with what is desired by the community. Romli Atmasasmita addresses that the Indonesian Code of Criminal Procedure adopt the accusatorial system and influenced by the due process model. The due process model highly upholds the rule of law. In a criminal case, no one can place themselves above the law. The accusatorial system relies much on the presence of witnesses and evidence.

The due process model recognizes the principle of presumption of innocence. According to this concept, every examination at the level of investigation, prosecution or examination in the Court must follow the formal procedures as stipulated in the law. Therefore the criminal justice system is closely related to both substantive and procedural criminal law.

\footnotetext{
9 Abdul Wahid, 2004, Sunardi, dkk “Kejahatan Terorisme Perspektif Agama, Ham dan Hukum”, Bandung, Published by PT.Refika Aditama, page. 112.

10 Trisno Rahardjo, 2011, “Mediasi Pidana Dalam Sistem Peradilan Pidana: Suatu Kajian Perbandingan dan Penerapannya di Indonesia", Published by Buku Litera, Yogyakarta, Page.60

11 Romli Atmasasmita, 2010, "Sistem Peradilan Pidana Kontemporer", Published by Kencana Prada Media Group, Jakarta,Page 122
} 
The Law Number 15 of 2003 on the Eradication of Criminal Acts of Terrorism qualifies some actions as criminal offence of terrorism as follows: 12

1. Article 6, Anyone who intentionally uses violence or threats of violence makes the atmosphere of terror or fear widespread to people or causes mass casualties, by seizing freedom or removing the lives and property of others or causing destruction of strategic vital objects or environmental or public facilities or international facilities punishable by death penalty or life imprisonment or imprisonment for a minimum of 4 (four) years and a maximum of 20 (twenty) years.

2. Article 7, someone who intentionally uses violence or threats of violence that is intended to cause an atmosphere of terror or fear to people at large or increase mass casualties, seize freedom or eliminate the lives and property of others or cause destruction of vital objects strategic or environmental or public facilities or international facilities sentenced to life imprisonment.

3. Article 8 , found guilty of committing a criminal act of terrorism with the same criminal offense as regulated in article 6, for anyone who: a) Destroying or causing buildings to be unusable or damaging buildings for the safety of air traffic or overcoming efforts to protect buildings; b) Causing damage or causing the building cannot be used or damaging buildings for the safety of air traffic or overcoming efforts to protect buildings; c) intentionally and illegally destroying, damaging, retrieving, or removing signs or devices to protect flights, or overcoming works from signs or devices, or installing wrong signs or wrong tools; d) because negligence causes a sign or tool to protect the flight from destroying, damaging, retrieving or moving or installing the wrong sign or the wrong tool to protect the flight; e) intentionally and illegally, destroying or damaging an aircraft that is wholly or partly owned by another person; $f$ ) intentionally and illegally endangering, destroying, damaging or damaging an aircraft; g) due to negligence causing the aircraft to be in danger, destroy, damage or damage; h) intentionally benefiting you or others illegally, because insurance guarantor causes fire or explosion, accidental damage, damage or causes the aircraft to be covered by insurance against danger or insured cargo and wages will be accepted for transportation, or for cargo interests have received a guarantee; i) acting against the law on an airplane, seizing or maintaining deficiencies or controlling the aircraft in flight; j) intentionally using violence or threats of violence or other forms of thread on the plane, seizing or maintaining seizure or controlling the aircraft in flight; k) appear together as a continuation of the planned bad conspiracy, causing the injured person, damage to the aircraft so that it can endanger his flight, carried out with the intention of seizing the freedom of others; 1) intentionally and illegitimate use of violence against anyone on the plane, if that could endanger their safety; $\mathrm{m}$ ) intentionally and illegally damaging an aircraft in service or causing a failure that makes it unable to fly or endanger aviation security; n) intentionally and illegally placed in aircraft that serve, in any way, tools or materials that can destroy the aircraft and cannot fly or cause damage that endangers aviation security; o) appear together, 2 (two) people or more as a continuation of a planned bad conspiracy, causing the injured person as stipulated in letters $1, \mathrm{~m}$, and $\mathrm{n} ; \mathrm{p}$ ) give a false statement and therefore can cause the security of

\footnotetext{
12 Abimanyu, B. (2007). Teror Bom Di Indonesia. PT. RajaGrafindo Persada, p. 234.
} 
the aircraft in danger; q) do something on the plane that can cause the security of the aircraft in danger; r) do something that can interfere with discipline and order on the plane.

4. Article 9, a person who illegally enters Indonesia, makes, receives, attempts to surrender or attempts to surrender, control, carry supplies, possess or possess in possession, store, transport, conceal, use or release to and / or from Indonesia something of a firearm, ammunition, explosives or something and other hazardous material with the intention of committing a criminal act of terrorism, punished by a death sentence or life imprisonment or imprisonment for a minimum of 3 (three) years and a maximum of 20 (twenty year.

5. Article 14, a person who plans and / or motivates others to commit acts of terrorism as referred to in Article 6, Article 7, Article 8, Article 9, Article 10, Article 11, and Article 12 shall be sentenced to death. life sentence or sentence.

6. Article 15, someone who committed a bad conspiracy, to try, or support a crime of terrorism as referred to in Article 6, Article 7, Article 8, Article 19, Article 10, Article 11, and Article 12 found guilty of punishment the same as the perpetrators of this crime.

7. Article16, a person who is outside the territory of Indonesia who provides assistance, simplicity, facilities, or a description of terrorism, is punished with the same punishment as the perpetrator of this crime as referred to in Article 6, Article

8. Article 8, Article 19, Article 10, Article 11, and Article 12.

9. Article 19, Provisions regarding minimum criminal penalties specifically referred to in Article 6, Article, Article 9, Article 10, Article 11, Article 12, Article 13, Article 15, Article 16 and provisions concerning the death penalty or life imprisonment. as stipulated in Article 14, it does not apply to terrorists under the age of 18 (eighteen) years.

The Indonesian government has executed 66 people around 1979 - 2015 due to various crimes including drug cases, murder, bombings, political crimes, and terrorism. Based on the Commission for Missing Persons and Victims of Violence (Kontras), the final execution for the death penalty was made upon 6 people in January 18, 2015 whose number became the third largest after 1986 (10 people) and 2008 (10 people). The following is a list of people sentenced to death in terrorism cases that have been executed: 13

1. Execution in 1983, Imron bin Mohammed Zein, mastermind behind piracy of the Garuda DC-9 aircraft route from Jakarta to Medan (1981);

2. 1985 execution, Salman Hafidz, Kosekta Cicendo 8606 Attack (1981);

3. Execution in 1991, Azhar bin Muhammad, terrorism;

4. Execution in 2008, Imam Samudra, Bali Bombing 2002;

5. Execution in 2008, Amrozi, Bali Bombing 2002;

13 Yunus, Y. (2013). Ini Daftar Terpidana Mati di Indonesia Yang Sudah Dieksekusi. http:/ / kabar24.bisnis.com/read/20150121/16/393285/ini-daftar-terpidana-mati-di-indonesia-yangsudah-dieksekusi [Accessed on August 8, 2018, at 10 am]. 
6. And Execution in 2008, Ali Gufron alias Mukhlas, 2002 Bali Bombing.

Table 1.

Legal and Institutional Framework on Counter-Terrorism: Comparison between Indonesia, Singapore and Malaysia.

\begin{tabular}{|c|c|c|}
\hline Indonesia & Singapura & Malaysia \\
\hline $\begin{array}{l}\text { Has Law No. } 15 \\
\text { of } 2003 \text { on Eradication of } \\
\text { Terrorism } \\
\text { - Law Enforcement } \\
\text { against terrorist in } \\
\text { Indonesia has been } \\
\text { regarded as the world } \\
\text { success story of counter- } \\
\text { terrorism. } \\
\text { - Indonesia is } \\
\text { currently in the phase of } \\
\text { drafting new regulations } \\
\text { to improve compliance } \\
\text { with international } \\
\text { standards. Has } \\
\text { - } \\
\text { preventive detention } \\
\text { clause as recognized } \\
\text { under the Internal } \\
\text { Security Act (ISA). } \\
\text { - Police (Densus } \\
88 \text { ) as the main actor of } \\
\text { law enforcement and } \\
\text { disruption network of } \\
\text { terrorist along with the } \\
\text { Attorney General and } \\
\text { justice system. }\end{array}$ & $\begin{array}{l}\text { The Singapore criminal } \\
\text { law does not specify the acts of } \\
\text { terrorism, but criminalize the } \\
\text { elements of planning, } \\
\text { preparation, and } \\
\text { implementation (murder, } \\
\text { kidnapping, etc). The highest } \\
\text { punishment is death penalty. } \\
\text { - Singapore often use } \\
\text { Internal Security Act } \\
\text { (ISA)/Internal Security ACT to } \\
\text { prevent and punish terrorism. } \\
\text { - There is preventative } \\
\text { detention clause that allows } \\
\text { the Internal Security } \\
\text { Department to detain someone } \\
\text { suspected as terrorists without } \\
\text { adjudication should it is set up } \\
\text { as a national security threat. } \\
\text { - There are special } \\
\text { detention facilities for } \\
\text { suspected terrorists (not mixed } \\
\text { in with the regular inmates). } \\
\text { - The authorities to } \\
\text { capture using the ISA is an } \\
\text { Internal Security Department } \\
\text { that has arresting power and } \\
\text { the similar investigation due to } \\
\text { Singapore Police. } \\
\text { - Singapore Police } \\
\text { enforce only handle ordinary } \\
\text { crimes. }\end{array}$ & $\begin{array}{l}\text { The fight against } \\
\text { terrorism through law } \\
\text { enforcement approach is } \\
\text { dominant in Malaysia. the } \\
\text { focus is on prevention } \\
\text { (preventative detention, } \\
\text { similar to Singapore). } \\
\text { - There are a number } \\
\text { of repressive legislation that } \\
\text { can be used to prevent and } \\
\text { suppress the spread of } \\
\text { terrorism: Internal Security } \\
\text { Act (ISA) or Internal Security } \\
\text { Law Act similar to } \\
\text { Singapore, Pers and } \\
\text { Publication Law Act, } \\
\text { Emergency Condition Law } \\
\text { Act, Sedition Act, State Secret } \\
\text { Law Act. Malasian Criminal } \\
\text { - Made } \\
\text { Code has special section to } \\
\text { criminalize terrorism and } \\
\text { antiterrorism laws being } \\
\text { special devise. However, the } \\
\text { most often used is Internal } \\
\text { Security Act (ISA) that } \\
\text { presses terrorism effectively } \\
\text { because it has a preventive } \\
\text { detention clause. } \\
\text { - Malaysian Police } \\
\text { lead in law enforcement } \\
\text { against terrorism. }\end{array}$ \\
\hline
\end{tabular}

Many efforts must be made to tackle the problem of terrorism in all its complexity in Indonesia. These efforts must be carried out with a holistic approach that includes the observation of intelligence services, handling by the Indonesian National Police and TNI, defense and security by the TNI, and total support from the people.

While related to prevention efforts, one of them is the Anti-Terrorism Bill urging immediate approval, but must remain grounded in due process of law that prioritizes 
the principle of fair trial. The Anti-Terrorism Bill is rumored to be oriented towards the 1960 Internal Security Act / ISA (Internal Security Act) owned by Singapore.

However, it should be noted that many law enforcement operations led to arbitrary detention of many people in the 1980s in Singapore on an ISA basis. Over the years since 1960, the ISA has been misused to accommodate mere political interests, such as suppressing dissidents (political opponents). For the past dozen years, efforts to prevent terrorism through the ISA have been at least successfully carried out against terrorist networks entering the country. Even so, many parties disagree with the ISA and propose to be replaced with the new AntiTerrorism Act.

Provisions regarding detention without trial (detention without trial) must be carefully considered because it will cause other new problems. Should the Anti-Terrorism Bill still accommodate these provisions? Human rights should not be disputed with nation rights. Both must walk together in preventing and overcoming terrorism in this country. Because the main goal is to provide access to law enforcement to act before the terror happens and consume more victims.

Besides that, what needs to be encouraged by the government is the people's love for the philosophy of this nation, namely Pancasila. The process of de-radicalization of suspected radicals, extremists and terrorists with doctrines which led to the rejection of Pancasila as the nation's ideology was also needed to prevent anti-Pancasila ideals from spreading and being imprinted into society.

TNI is expected to synergize with the Indonesian National Police in maintaining the integrity of the Republic of Indonesia, as mandated by the TNI Law. This is done by strengthening defense at the national border in order to protect the country's national security. Efforts to prevent terrorism are things that need to be prioritized in the AntiTerrorism Bill. This prevention is important to be carried out by law enforcement before terror occurs so that major damage can be avoided. Not to forget, there needs to be criminal provisions regarding Indonesian citizens who go to other countries to undergo war training or other recruitment related to terrorism

\subsection{Counter-Terrorism from the Perspective of Pancasila}

If associated with the constitution, counter-terrorism is a form of protection against citizens as mandated by the 1945 Constitution of the Republic of Indonesia (1945 Constitution). The Indonesian government has duty and responsibility to maintain a safe, peaceful and prosperous life and actively maintain world peace.

Beside employing the criminal justice system, counter-terrorism can also employ social and educational system especially by involving the young generation. The danger of terrorism should have been introduced to the youths. For this purpose, counterterrorism should be incorporated into school curriculum to complement the Pancasila ${ }^{14}$ basic education. This to allow the young generation of Indonesia learning about the important values contained in Pancasila such as tolerance and peace. As suggested in

\footnotetext{
14 Pancasila is the state's ideology of Indonesia. Pancasila that literally means five pillars lays down five fundamental principles for the citizens.
} 
the motto "Unity in Diversity (Bhineka Tunggal Ika), they will learn that differences are not a mistake. ${ }^{15}$

The implementation of the Pancasila requires conscience and commitment from all citizens. It must begin with the good understanding on the values contained in each principle. First principle, believing in one supreme God, gives freedom to all people to embrace religion in accordance with their respective beliefs and beliefs. ${ }^{16}$ Second principle, humanity, is a form of appreciation for human dignity as human rights. Third principle, unity, upholds unity above all personal and group interests. Fourth principle, democracy, reflects every decision-making based on consensus to reach consensus, in reaching consensus everyone has the right to express his opinion and every deliberation to reach consensus must be borne by family spirit. Fifth principle, social justice, develops a fair attitude towards others, respects the rights of others, carries out activities to achieve equitable progress and social justice.

With regard to this, the youths can play more significant role by socialising the teaching of Pancasila basic education to the community both in the city and in the village. The socialization carried out by the young generation will help provide better understanding on Pancasila not only for the community but also for themselves.

\section{Conclusion}

Indonesia has established sufficient legal and institutional framework for combating terrorism. The current legal basis for combating terrorism in Indonesia is The Government Regulations in Lieu of Statute (Perpu) No. 1 of 2002 on the Eradication of Terrorism. The fight against terrorism involves various institutions including national police, national army, and civil society. With regard to this, special unit has been established to deal with terrorism by national police and national army as well to the establishment of anti-terror units from the TNI, police or non-governmental institutions, where the Police (Densus 88) are the main actors in law enforcement against terrorism together with the Attorney General and the justice system. For future development, it seems to be necessary to adopt preventive detention clause that allows the detention against terrorist suspect without adjudication when necessary. As comparison, under the Internal Security Act (ISA) in Singapore and Malaysia, preventive detention can be done as long as it is designated as a national security threat.

\section{References}

Books:

Abimanyu, B. (2007). Teror Bom Di Indonesia. PT. RajaGrafindo Persada.

Amiruddin \& Asikin, Z. (2004). Pengantar Metode Penelitian Hukum. PT. RajaGrafindo Persada.

Atmasasmita, R. (2010). Sistem Peradilan Pidana Kontemporer. Kencana Prada Media Group.

\footnotetext{
15 Masyhar, A. (2009). Gaya Indonesia Menghadang Terorisme, Sebuah Kritik Atas Kebijakan Hukum Pidana Terhadap Tindak Pidana Terorisme Di Indonesia. Mandar Maju, p. 70.

16 Syamsudin, A. (2008). Integritas Penegak Hukum. Kompas Publisher, p. 53.
} 
Golose, P.R. (2010). Deradikalisasi Terorisme Human Soul Approach dan Menyentuh Akar

Rumput, Yayasan Pengembangan Kajian Ilmu Kepolisian, p. 2.

Hendropriyono, A. M. (2010). Politik Para Teroris. Kanisius.

Masyhar, A. (2009). Gaya Indonesia Menghadang Terorisme, Sebuah Kritik Atas Kebijakan Hukum Pidana Terhadap Tindak Pidana Terorisme Di Indonesia. Mandar Maju.

Nacos, B. L. (2010). Terrorism and Counter-Terrorism: Understanding Threats and Responses in the post- 9/11 World. Longman.

Purwanto, W.H. (2004). Terorisme Ancaman Tiada Akhir. Grafindo Khazanah Ilmu.

Rahardjo, T. (2011). Mediasi Pidana Dalam Sistem Peradilan Pidana: Suatu Kajian Perbandingan dan Penerapannya di Indonesia. Buku Litera.

Ramelan, P. (2009). Intelijen Bertawaf. PT.Gramedia Widiasarana Indonesia.

Syamsudin, A. (2008). Integritas Penegak Hukum. Kompas Publisher.

Wahid, A., Sidik, M.I., \& Sunardi. (2004). Kejahatan Terorisme Perspektif Agama, HAM dan Hukum. PT.Refika Aditama.

Wahjuwibowo, I. S. (2015). Terorisme Dalam Pemberitaan Media, Analisis Wacana Terorisme Indonesia. Deepublish.

Wardlaw, G. (2017). Political Terrorism. Cambridge University Press

Wreksosuhardjo, S. (2015). Pancasila Menggali Kecerdasan Pikir dan Jiwa bangsa Indonesia Sebagai Harta Terpendam. UPT UNS Press.

\section{Journal Articles:}

Setyanto, A. (2013). Opini Publik Terhadap Terorisme di Eropa: in the case of Norway's attack on 2011. Jurnal Hubungan Internasional, 4(1), 41-56.

\section{Papers:}

Chalk, P. (2002). Terrorism in Southeast Asia Springboard for International Terrorist Attack, University of Colorado Denver, Institute for International Business and CenterInternational Business Education \& Research, Global Executive Forum.

Schmid, A. (2004). The Defitional Problem. British Ambassador to the United Nations, in post September 11, 2001.

\section{Internet:}

Bappenas, Pencegahan dan Penanggulangan Terorisme. http://www.bappenas.go.id/get-file-server/node/6159/. [Accessed on August ,1, 2018].

Ghufron. (2017). Radikalisme dan Politik Identitas. http://nasional.kompas.com/read/2017/05/05/19170871/radikalisme-danpolitik-identitas. 
Mulyana, W Kusuma, M.W. Terorisme Dalam Perspektif Politik dan Hukum. https://media.neliti.com/media/publications/4223-ID-terorisme-dalamperspektif-politik-dan-hukum.pdf [Accessed on December 22-29, 2002].

Rozi, F. (2017. Radikalisme Ancaman Nyata Pemuda Tanah Air. Liputan6. http://news.liputan6.com/read/3034980/radikalisme-ancaman-nyata-pemudatanah-air.

Sa'dullah, A. (2016). Akar Sejarah Gerakan Radikalisme Indonesia. Wahid Foundation. http:// wahidfoundation.org/index.php/news/detail/Akar-Sejarah-GerakanRadikalisme-di-Indonesia Fathurrohman

Susanti, R. (2015). Survei: Terorisme Internasional, Kejahatan Paling Disorot Media Online Sepanjang 2015.

http://nasional.kompas.com/read/2015/12/27/09102341/Survei.TerorismeInternasional-Kejahatan-Paling-Disorot-Media-Online-Sepanjang-2015 [Accessed on August, 1, 2018].

Ucu, R. (2012). Perlu Strategi Baru Hadapi Terorisme. https://www.republika.co.id/berita/nasional/umum/12/03/16/m0zhsbhabibie-perlu-strategi baru hadapi-terorisme [Accessed on July 28, 2012].

Yunus, Y. (2013). Ini Daftar Terpidana Mati di Indonesia Yang Sudah Dieksekusi. http://kabar24.bisnis.com/read/20150121/16/393285/ini-daftar-terpidanamati-di-indonesia-yang-sudah-dieksekusi [Accessed on August 8, 2018, at 10 am].

\section{Regulations:}

Undang-Undang No.15 Tahun 2003 tentang Penetapan Peraturan Pemerintah Pengganti Undang-Undang No.1 Tahun 2002 tentang Pemberantasan Tindak Pidana Terorisme menjadi Undang-Undang Jo. Peraturan Pemerintah Pengganti Undang-Undang No.1 Tahun 2002 tentang Pemberantasan Tindak Pidana Terorisme . 